馬鈴薯疫病抵抗性の細胞生理学的研究

VII 抵抗性および䍜病性を示す馬鈴薯葉柄生細胞内に於ける 疫病菌菌系伸長の比較

\title{
富山宏 平*
}

Kohei Tomyama : Cell physiological studies on resistance of potato plants to

Phytophthora infestans.

VII. Growth of intracellular hyphae of Phytophthora infestans in the living potato plant cells which are resistant or susceptible to the infection of them.

前報告3)で筆者は, 疫病菌の侵入を受けた抵抗性馬 鈴萻品種の細胞が過敏感死を示す時期に，大部分の侵 入菌系は生きており，かつ伸長能力をむつていること を示した。そこで疑問となることは，寄主細胸の過敏 感死以前に抵抗性の細胞内の菌系の伸長が何らかの阻 害を受けていないかと云うことであろう。ここに述べ る実験ねこの点を明かにしようとする目的でなされた。

\section{I. 実 験 法}

前報告 ${ }^{3}$ における供試部位は稚葉の中肋表皮細胞で あつた。この細胞は菌侵入後の過敏感反応がきわぬて 速やかで), 過敏感死以前の菌系伸長の測定は困難で! ある。そこで今回は葉柄を㢦刃で緱断し，その切断面 の破塤細胞の内容を除くために流水洗し，その皮層組 幾に疫病菌の遊走子浮遊液を接種した。接種後検鏡す ると, 乙の切断面の細胞は生きていて（生体染色, 原 形質流動により確認),遊走子は大部分, 乙の生細胞壁 に附着器をつくつて唚入し, 稀にある筀細胞（破壊細 盷）壁に附着器をつくつて侵入したものとは形態を全 く異にしているから，生細胞内の菌系を測定できる。

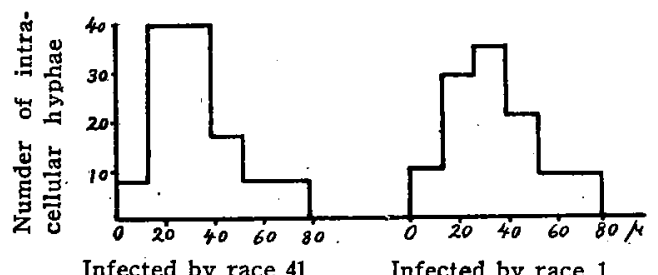

Fig.1. Distribution of the length of 'intracellular hyphae in the cells of Hokkai No. 10,6 hrs. after inoculation

ての組織では被侵害細胞の死はほほ 10〜15 時間 後5)

* 北海道農業試験場
に起るから充分に過敏感死前の生細胞内菌系伸長を測 定する時間がある。これを $19^{\circ} \mathrm{C}$ の定温器に入れて処 定時間後とり出して㷙刃で検鏡用切片をつくり直ちに Bouin 固定液・(第2,3 表の実験) あるいは Forma-

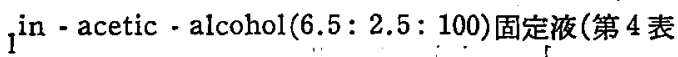
の実験)で固定した。Bouin 固定液の場合は70\%エ チルアルコールで洗深したのち検鏡 し, Formalinacetic-alcohol の場合注そのまま検鏡した。接種後 6 時間程度では菌系は分岐著しく少なく，且つ比較的 屈曲少なく，伸長するので接種後および，46時間目 に固定した。疫病菌の細胞内侵入はこれらの材料では ほぼ 2 2.5時間で完了する5)。

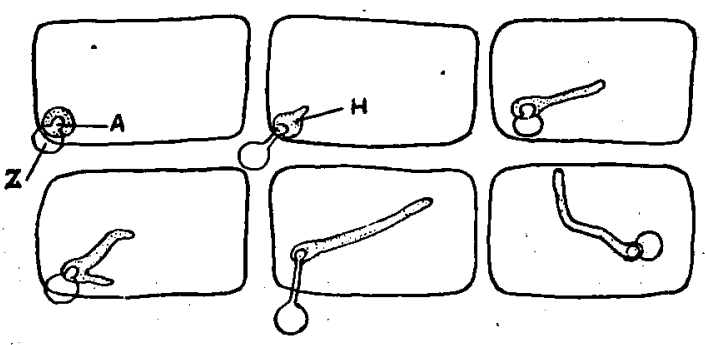

Fig. 2. Intracellular hyphae of Phytophthora infestans.

A : appressorium

$\mathrm{H}$ : intracellular hyphae

$Z$ : zoospore

この場合菌系の進入角度, 屈曲が測定上の誤差の原 因となることは云う迄むないが，しかし条件住抵抗性， 罹病性で同じなので，誤差も同じと見做される。した がつて充分比較に耐党ると考えられる。測定はミクロ メーターにより階級に分けて測定したのち平均した。 観察細胞数は各反覆でおのおの 100 130 て時にそれ より少ない場合もあつた。菌系の状態の一例を Fig. 2. 
Table 1. Reactions of the potato varieties used in the present experiments to races of P.infestans.

直後のむのから, 相当に伸長したも

\begin{tabular}{|c|c|c|c|c|c|c|}
\hline \multicolumn{3}{|c|}{ Varieties } & $\begin{array}{l}\text { Irish } \\
\text { Cobbler }\end{array}$ & $\begin{array}{l}\text { Hokkai } \\
\text { No. } 10 \\
\end{array}$ & $\begin{array}{l}48005-46, \\
\text { Hokkai No. } 17\end{array}$ & $41089-8$ \\
\hline \multicolumn{3}{|c|}{ Genotypes* } & I & $\mathrm{R}_{1}$ & $\mathbf{R}_{\mathbf{4}}$ & $R_{1} R_{4}$ \\
\hline \multirow{4}{*}{$\begin{array}{l}\text { Reactions } \\
\text { to the race * }\end{array}$} & Race & 0 & $S$ & $\mathrm{R}$ & $\mathbf{R}$ & $\mathrm{R}$ \\
\hline & Race & 1 & $S$ & S & $\mathbf{R}$ & $\mathbf{R}$ \\
\hline & Race & 4 & $\mathrm{~S}$ & $\mathbf{R}$ & $\mathrm{S}$ & $\mathrm{R}$ \\
\hline & Race & 1,4 & $\mathrm{~S}$ & $\mathbf{S}$ & $\mathbf{S}$ & $\mathrm{S}$ \\
\hline
\end{tabular}
のまで種々の長さ のものが混在して いる。この長さの 分布の一例を図示 すると Fig. 1 の ようになる。全体 の測定を通覧す

Remark: * According to the international nomenclature proposed by Black et al.

$$
\text { (Takase }{ }^{2),} \text { Takakuwa and Takase }{ }^{8} \text { ) }
$$

るにこの分布の形 は抵抗性を示す場 合と霍病性を示す

に示した。

供試馬鈴暮品種としては抵抗性因子 $\mathbf{R}_{\mathbf{1}}$ および $\mathbf{R}_{\mathbf{4}}$ を 各単独に，または併せもつたもの（高瀬2）を用い， それらに対して病原性をるつ疫病菌系統および病原性 をもたは系統を接種した。これら供試材料の性質を第 1 表に示した。

実験は 1955〜156 の間に3 回行つた。各実験でそ れぞれ 2 3 回の接種試験をくり返えした。

\section{2 実 験 結 果}

細胞内における菌系の伸長程度を観測すると，侵入
場合とで差を見なかつた。したがつてこれらの測定值 から平均値を計算することによつて，抵抗性と䍜病性 の場合における生細胞内の菌系伸長を比較することが できるであろう。

生細胞内の菌糸伸長の測定結果を Table 2 4 した。これらの諸表から, 各系統の疫病菌の生細胞内 の伸長速度は品種間では統計的に意義のある差を見ず 特に抵抗性との間には全く相関を認めない。ここで興 味があるのは疫病菌の系統によつて生細胞内の菌系伸 長が異なる点である。すなわち Table 3 では race4 の伸長が悪く, Table 4では race 1,40伸長が悪い

Table 2. The length of intracellular hyphae of

Phytophthora infestans in the cells of cortex layer of petioles of potato variety Hokkai No. 10.

\begin{tabular}{|c|c|c|c|c|c|c|}
\hline $\begin{array}{l}\text { Hrs.after } \\
\text { inoculation }\end{array}$ & \multicolumn{2}{|c|}{4} & \multicolumn{2}{|c|}{6} & \multicolumn{2}{|c|}{$\begin{array}{c}\text { The difference between } \\
4 \text { and } 6 \\
\text { (Growth rate for } 2 \text { hrs.) }\end{array}$} \\
\hline $\begin{array}{l}\text { Races of } \\
P \text {.infestans }\end{array}$ & Race 0 & Race 1 & Race 0 & Race 1 & Race 0 & Race 1 \\
\hline $\begin{array}{l}\text { Reactions of } \\
\text { host plant }\end{array}$ & $\mathbf{R}$ & S & $\mathbf{R}$ & $\mathrm{S}$ & $\mathrm{R}$ & $\mathrm{S}$ \\
\hline I (Means) & 17.5 & $21.6 \quad \mu$ & 30.6 & 27.5 & 13.1 & 5.9 \\
\hline II $(" \prime)$ & 21.3 & 20.5 & 32.7 & 35.6 & 11.4 & 15.1 \\
\hline Means & 19.4 & 21.1 & 31.7 & 31.6 & 12.3 & 10.5 \\
\hline
\end{tabular}

これらの場合にそれぞれの系統は分離後日が浅く，馬 鈴薯生塊宔上での菌糸発育は不良であつた。これらの 菌系統の発育が篗病性細胞の中でる抵抗性細胞の中で と同様に著しく覀いと云うことは，菌の生細胞内の発 育速度と R因子による抵抗性とが一応無関係であるこ とを示しているように思われる。

\section{3 論議}

以上述べた実験結果から， $\mathrm{R}_{\mathbf{1}}$ ，及び $\mathrm{R}_{\mathbf{4}}$ 因子に基く 疫病抵抗性では, 侵入後少なくも約 4 時間以内には,
侵入菌糸の伸長阻害は認められない。これらの材料厄 は，寄主細胞の過敏感死はおおむね 10〜15 時間 5)で あるから, 寄主細胞の過敏感死の直前に菌禾伸長の阻 害があるかどうかについては，この実験結果からは云 うことができない。しかし過敏感死が始まる時期の観 察によれば, 細胞内の菌系の蔓延状況については特別 に抵抗性及び㷳病性間に差があるよらには見えない。

現在迄のところるつとも抵抗性と密接应関係がある と思われる細胞学的な現像は寄主細胞の過敏感死に要 ナる時間である(,6,6)。 
Table 3. The length of intracellular hyphae of Phytophthora infestans in the cells of cortex layer of petioles of potato varieties Hokkai No. 10 and $48005-46$.

\begin{tabular}{r|c|c|c|c}
\hline Potato varieties & Hokkai & No. 10 & \multicolumn{2}{|c}{$48005-46$} \\
\hline Races of $P$. infestans & Race 4 & Race 1 & Race & Race \\
\hline Reactions of host \\
plant
\end{tabular}

Remarks: 1) * This figure was omitted from calculation of mean, because of the small number of observed cells.

2) Statistical significance of the difference between mean values of growth rate for two hours is :-

Between varieties : insignificant $\left\{F_{0}=2.14, F_{6}^{1}(0.05)=5.99\right\}$

Between races : highly significant $\left\{F_{0}=82.1, F_{6}^{1}(0.01)=13.74\right\}$

Interaction between varieties and races : insignıficant $\left\{F_{0}=5.55, F_{6}^{1}(0.05)=5.99\right\}$

すなわち抵抗性を示す場含には菌侵入に伴う過敏感 死が速やかで，惟病珄を示す場合には遅い。前報告 で,“寄主細胞の死直後（褐变初期）に侵入菌系は生き ていて，かつ伸長能力を持つている”ことを証明した が，本実驗の結果は寄主細胞が生きている場合には菌 糸の伸長の阻害すらも殆ど起つていないことを示して いる。

寄主細胞の過敏感死以後に急激な菌系伸長の阻害が 認められるが，これらの現象については別に報告し $\left.\kappa^{3}, 6,7\right)$ 。

\section{4 摘 要}

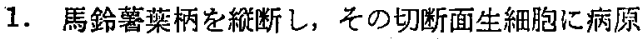
性を異にした疫病菌の各系統を接種し 4 及び6時間後 に固定し，皮層細胞内の菌糸伸長を測定した。

2. その結果 $R_{1}$ および $R_{4}$ 因子による抵抗性にお
いては寄主細胞の過敏感死以朔の時期に法，少くも侵 入後約 4 時間以内では侵入菌糸伸長阻害は認められな いととが明らかになつた。 (1956年11月30日受理)

\section{引用 文 献}

1）高桑亮・富山宏平： 北海道㟽試桑報, $73: 94 \sim 99$. (1957)；日植病報，21：37.(1956).

2) 高瀬异：育種学雑誌，6 (別刷)：12.(1956)

3）富山宏平：日植病報，19：149 154,.(1955)

4) — : 同上, $20: 165 \sim 169 .(1956)$.

5) - : 日植病学会北海道部会31年度請演(1956).

6) 一一：農業技術, $11: 63 \sim 67$.(1956)：

7) 一一高瀬昇・酒井隆太郎・高桑亮・竹森俊彦 ：日植病報, $21 ： 109 .(1956)$.

8) 高桑亮・高瀬昇：北農研究抄報，3号。 
Table 4. The Iength of intracellular hyphae of $P$. infestans in cells of cortex layer of petioles of potato varieties, Irish Cobbler, Hokkai No. 10, Hokkai No. 17 and 41089-8.

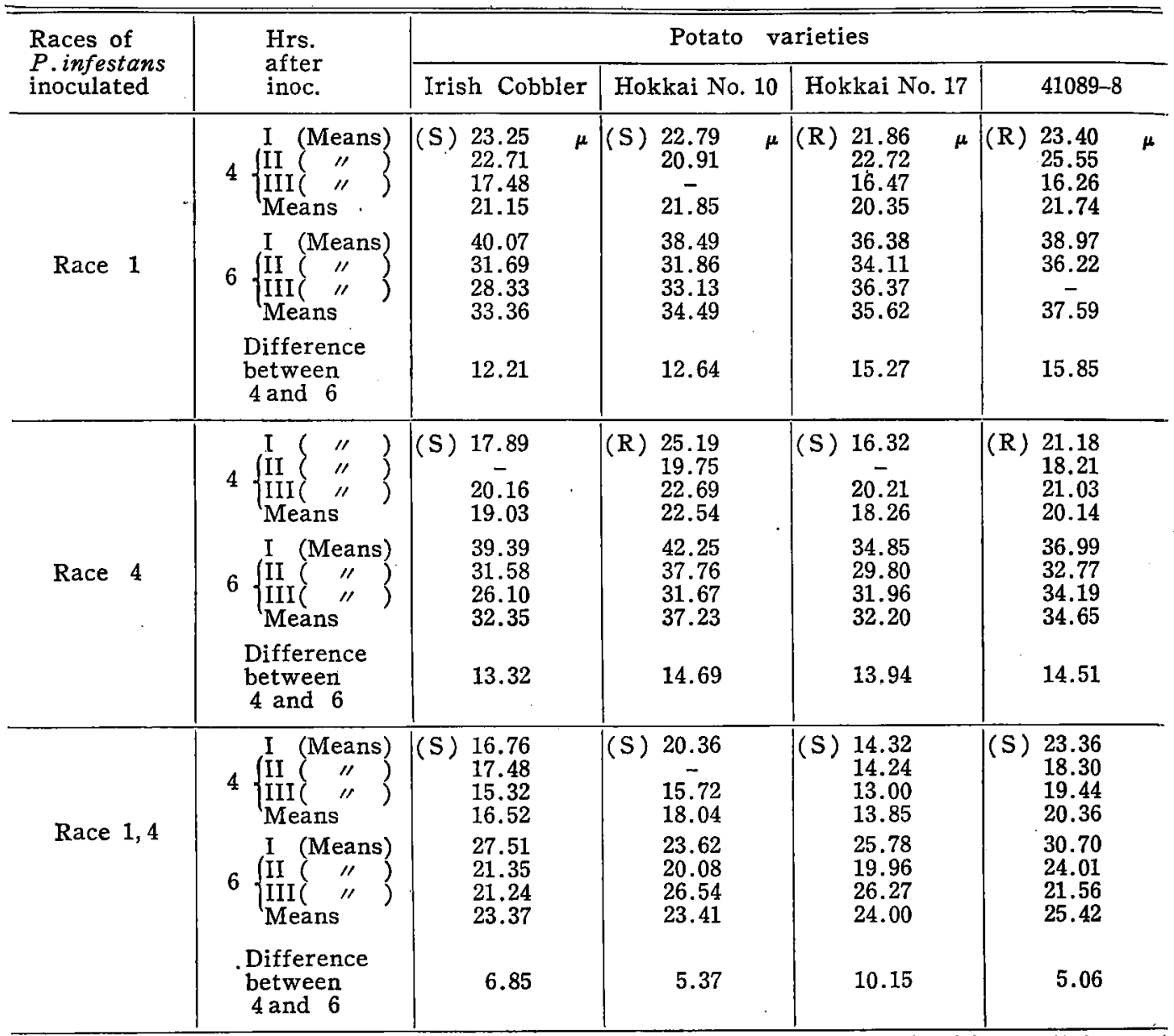

Remark: Statistical significance of the difference between the length of intracellular hyphae $6 \mathrm{hrs}$. after inoculation is :

Between varieties : insignificant $\left\{F_{0}=1.497, F_{22}^{3}(0.05)=3.05\right\}$

Between races : significant $\left\{\mathrm{F}_{0}=57.19, \mathrm{~F}_{22}^{2}(0.01)=5.72\right\}$

Interaction between varieties and races, insignificant $\left\{F_{0}=0.89, F_{22}^{6}(0.05)=2.55\right\}$

\section{Résumé}

In the previous paper ${ }^{3}$, it was shown by means of vital staining that the majority of the intracellular hyphae of Phytophthora infestans in cells of a resistant potato variety were still living at an early stage of necrosis of host cell.

The present experiments have been carried out, in order to ascertain, furthermore, whether the growth of intracellular hyphae is inhibited or not, before the hyper-sensitive dea- th of host cell.

A petiole of potato leaf was cut longitudinally with a razor, and washed with streaming water in order to eliminate the contents of destroyed cells. The cut surface of the petioles, almost all the cells of which were living, was inoculated with $P$. infestans. Four and 6: hours after inoculation, microscopical sections of the inoculated materials were prepared and fixed with Bouin or Formalin-acetic-alcohol, and 
then the length of intracellular hyphae was measured with a micrometer. As the hypersensitive death of the host cells, caused by. infection with the incompatible race of $P$. infestans, occurs about 10-15 hours after inoculation, the values thus obtained may indicate the growth rate of the fungus in living cells. In the materials used in the present experiments, penetration took place about 2-2.5 hours after inoculation.

The varieties tested were Irish Cobbler ( $\mathrm{r}$ ), Hokdai No. $10\left(R_{1}\right)$, Hokkai No. $17\left(R_{4}\right), 48005-46$ $\left(R_{4}\right)$ and $41089-8\left(R_{1} R_{4}\right)$. These varieties were inoculated with compatible or incompatible races of $P$. infestans: race 0 , race 1 , race 4 and race 1,4 .

The results obtained are as follows. The -differences in the growth rate of the hyphae in the living cells is statistically highly signifi- cant between races, but not between varieties.

The interaction between varieties and races is not statistically significant.

From these results, it may be concluded that, even when the host plant cells show resistance to infection by $P$. infestans owing to presence of resistant genes $R_{1}$ and $R_{4}$, the growth of intracellular hyphae of the pathogen is not inhibited, at least, within about 4 hours after penetration.

From the accumulated knowledge in this respect, it seems that the most evident cytological phenomenon having close connection with late blight resistance is the time elapsed from penetration of the fungus to the hyper-sensitive death of a host cell. $8,6,7)$

(Hokkaido National Agricultural Experiment Station, Sapporo)

\section{雑録}

\section{タバコ黒色根病病菌の新単離法}

Tadao SHimizu: A new method for isolation of Tielaviopsis

basicola.

清 水 忠 夫*

タハコ黒色根腐病菌 Thielaviopsis basicola は打 加主部分が士䖯中の部分であるから単離が困難な菌の ひとつである。従来その戦離には特殊な培地を用いた りまたメトリ且に洰紙をおき，ての上で夕バコを発 芽させ，発芽直後の子葉に胞子浮游液を散布する方法 が用いられている。著者は本病におかされたタバコの 一根扰よび土境から本菌を容易に単離し, 同時に病原性 の検定にも応用できるひとつの新しいタバコの茎を用 いた方法を考案した。この方法によれば極めて簡単に 確実に単離されるようである。

まず根の病斑部から分離しようとするならば, 無病 と思われる本病に感受性の高い品種の若いタバ（草 文 $20 \mathrm{~cm}$, 幹径 $0.8-1.0 \mathrm{~cm})$ の葉を除いた茎を，0.1\% 昇丞水に浸漬し蒸溜水で洗湺した後, 消毒した刃物で $-5.6 \mathrm{~cm}$ ぐらいの長さに切る。その中間に70\%アルコー ルで消毒した三角刀をむつて，縱に約 $1 \mathrm{~cm}$ 深さ䯣に 達する傷をつけて病組織片を捚入する。接種した茎は、 *秦野たばこ試験場
水を含ませた沪紙（石英砂でもよい）を入れた，予め 消毒しておいたハトリ血に入れる。それを $20^{\circ}-26^{\circ} \mathrm{C}$ の恒温器におけば 2 日ないし 6 日で病組織片を挿入し た部分と両端の切口とに, 内生胞子および厚膜胞子と を生ずる。これらの胞子のうち切口に生じた部分から 白金耳で殺菌水に移し，さらに馬鈴薯寒天培地に移せ ば純粋培責がえられる。土塞よりの分離は,ササゲ $(V i-$ gna sinensis) を発病させ，その病斑部から前記の 方法で単離できる。菌はタハコの菜のなかを通つて両 端に出てくるが，てのとき他のタハコに笴生性のない 菌は，タハコの茎のなかを通ることができないから， たやすく純粋培養がえられる。

この方法によれば，胞子形成の良好なものは，いず れも感受性品種であり，抵抗性の強いものは菌の生長 がわるい。抗抵性の差が胞子形成の多少，または菌の 生長によつて認められるから，この方法によつて抵抗 性品種のある程度の室内検定に適用することができる と思市能る。 